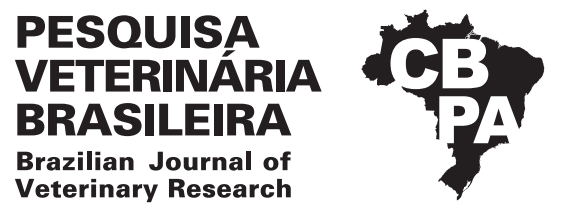

Pesq. Vet. Bras. 39(4):251-254, April 2019 DOI: 10.1590/1678-5150-PVB-6170

Original Article

ISSN 0100-736X (Print) Livestock Diseases

ISSN 1678-5150 (Online)

\title{
High frequency of cutaneous squamous cell carcinoma in Friesian Milchschaf sheep in Uruguay ${ }^{1}$
}

\author{
Ricardo A. Costa ${ }^{2}$, Carlos Schild², Dario Caffarena², Federico Giannitti ${ }^{2}$, \\ Georgett Banchero ${ }^{2}$, Liliana DelPino ${ }^{3}$ and Franklin Riet-Correa ${ }^{2 *}$
}

\begin{abstract}
Costa R.A., Schild C., Caffarena D., Giannitti F., Banchero G., DelPino L. \& Riet-Correa F. 2019. High frequency of cutaneous squamous cell carcinoma in Friesian Milchschaf sheep in Uruguay. Pesquisa Veterinária Brasileira 39(4):251-254. Instituto Nacional de Investigación Agropecuaria, Estación Experimental INIA La Estanzuela, Ruta 50 Km 11, Colonia del Sacramento, Colonia, Uruguay. E-mail: frcorrea@inia.org.uy

This study described five cases of squamous cell carcinoma (SCC) in the pinnae, eyelids, and eyes of Friesian Milchschaf sheep from two flocks raised under extensive conditions in Uruguay. The prevalence values for both flocks were $2.12 \%$ and $2.53 \%$, respectively. Macroscopically, single or multiple, nodular, verrucous, or plaque-like neoplasms, with occasional ulceration and bleeding, were observed in the affected areas. Histologically, well- and moderately-differentiated SCCs were diagnosed in three and two cases, respectively. The Milchschaf breed is native of Germany, and its individuals present white non-pigmented skin with the face and legs clear of fleece, thus adapted to areas with lower solar radiation. Additionally, in the German breeding systems, animals remain indoors for long periods. The increased exposure time to higher levels of solar radiation of the Uruguayan extensive production systems may be a predisposing factor for the development of SCC in this sheep breed. In Uruguay, there is more solar radiation and the production systems provide less protection against sunlight compared with the German production system. The high frequency of SCC should be considered prior to introducing European breeds with non-pigmented skin in Uruguay and other countries of the region.
\end{abstract}

INDEX TERMS: Cutaneous carcinoma, squamous cell carcinoma, Friesian Milchschaf, sheep, Uruguay, tumors, neoplasm, sheep diseases, skin diseases, dermatopathology, pathology.

\footnotetext{
RESUMO.- [Alta frequência de carcinoma cutâneo de células escamosas em ovinos da raça Frisona Milchschaf no Uruguai.] Descreveram-se carcinomas de células escamosas (CCE) nas orelhas, pálpebras e olhos em cinco ovinos da raça Frisona Milchschaf em dois rebanhos de criação extensiva no Uruguai. A prevalência nos rebanhos foi de 2,12\% e 2,53\%. Macroscopicamente se observaram lesões focais ou multifocais, com aumento de volume, nodulares, verrucosas ou em placas, com ocasionais ulcerações e

${ }^{1}$ Received on December 3, 2018.

Accepted for publication on December 12, 2018.

${ }^{2}$ Instituto Nacional de Investigación Agropecuaria (INIA), Estación Experimental INIA La Estanzuela, Ruta $50 \mathrm{Km} 11$, Colonia del Sacramento, Colonia, Uruguay. E-mails: costa.ricardoalmeida@gmail.com, coloschild@gmail.com, rdcaffarena@gmail.com, fgiannitti@inia.org.uy, gbanchero@inia.org.uy; *Corresponding author: frcorrea@inia.org.uy

${ }^{3}$ Instituto Nacional de Investigación Agropecuaria (INIA), Estación Experimental INIA Las Brujas, Ruta 48 Km 10, Rincón Colorado, Canelones, Uruguay. E-mail: Idelpino@inia.org.uy
}

hemorragias. Apresentavam aspecto verrucoso, por vezes com superfície ulcerada e firmes ao corte. De acordo com as características histológicas da neoplasia, as lesões foram classificadas em CCEs bem diferenciados em três casos e moderadamente diferenciados em dois casos. Esta raça é nativa da Alemanha, caracterizada pela face deslanada e pele branca despigmentada. Na Alemanha, há menores níveis de radiação solar do que no Uruguai e seu sistema de produção é mais intensivo, com permanência dos animais confinados durante longos períodos. 0 aumento do tempo de exposição a níveis mais elevados de radiação solar pode ser um fator predisponente para o desenvolvimento de CCEs nesta raça em sistemas extensivos de produção no Uruguai. Neste País há mais radiação solar e os sistemas produtivos fornecem menos proteção contra a luz solar, em relação ao sistema de produção alemão. A alta frequência de CEE deveria ser levada em consideração para quem decide introduzir no Uruguai e outros países da região. raças europeias com a face despigmentada. 
TERMOS DE INDEXAÇ̃̃O: Carcinoma cutâneo, células escamosas, ovinos, Frisona Milchschaf, Uruguai, tumores, neoplasma, doenças de ovinos, doenças de pele, dermatopatologia, patologia.

\section{INTRODUCTION}

Squamous cell carcinomas (SCCs) are malignant neoplasms of epithelial origin with keratinocyte differentiation (Ramos et al. 2007, Goldschmidt \& Goldschmidt 2016). They are most common in horses, cattle, dogs and cats, uncommon in sheep, and rare in goats (Barbosa et al. 2009). Although these neoplasms present higher incidence in senile animals, they may occur in young animals, especially when associated with other risk factors such as exposure of areas with poor pigmentation and little hair to ultraviolet (UV) rays (Goldschmidt \& Goldschmidt 2016, Mauldin \& Peters-Kennedy 2015). Ovis aries Papillomavirus 3 infection (Alberti et al. 2010, Vitiello et al. 2017) as well as traumatic skin lesions (Goldschmidt \& Goldschmidt 2016) may also be risk factors for the emergence of neoplasms in sheep.

Although SCC can develop in any anatomical region of the skin, it is predominant in mucocutaneous junctions such as eyelids, conjunctiva, vulva, and perineum in cattle (Fernandes 2007, Ramos et al. 2007, Carvalho et al. 2014, Mauldin \& Peters-Kennedy 2015), whereas the face is the most commonly affected region in sheep, especially the pinna (Mauldin \& Peters-Kennedy 2015), followed by the muzzle, lips, eyelids, and eyes (Ramos et al. 2007, Carvalho et al. 2014). Traumatic cutaneous lesions may also be a risk factor for the emergence of neoplasms in sheep (Goldschmidt \& Goldschmidt 2016), and the diagnosis should be based on histology.

This study aimed to report the occurrence of SCC in Friesian Milchschaf sheep from two flocks in Uruguay and discuss the possible causes of the high prevalence of this disease in some sheep breeds.

\section{MATERIALS AND METHODS}

During technical visits to the production farms, all the sheep under study were clinically assessed and epidemiological data were collected. Biopsy was performed in the affected regions of two animals and three other sheep were necropsied. The samples were fixed in 10\% formalin, dehydrated, paraffin embedded, cut into 4-5 $\mu$ m sections, and stained using the hematoxylin-eosin (HE) technique.

Ultraviolet (UV) radiation in the region of origin of this breed - East and North Friesland $\left(53^{\circ} \mathrm{N}\right)$, Germany, were compared with those recorded in La Estanzuela $\left(34^{\circ} \mathrm{S}\right)$, Colonia, and Rincón del Colorado $\left(34^{\circ} \mathrm{S}\right)$, Canelones, in Uruguay, which are areas located near the farms where the cases occurred. The World Health Organization (WHO 2017) UV classification scale, which ranges from 1 to 12 according to the levels of UV radiation in various capital cities of the world, was used. According to this scale, UV radiation levels are classified as low (1 and 2), moderate (3,4 and 5), high (6 and 7), very high $(8,9$ and 10$)$, and extreme $(>10)$. The latitudes $34^{\circ} \mathrm{S}$ and $52^{\circ} \mathrm{N}$ were used as reference to compare La Estanzuela and Rincón del Colorado, in Uruguay, and East and North Friesland, in Germany.

\section{RESULTS}

The first farm, located in La Estanzuela, Colonia $\left(34^{\circ} 47^{\prime} 13^{\prime \prime} \mathrm{S}\right.$, $57^{\circ} 84^{\prime} 41^{\prime \prime} 0$ ), was visited in July 2015 . In this property, 481 adult sheep (282 Texel, 80 Finnish Landrace, and 79 Friesian Milchschaf, and their respective crosses) were raised in an area of 80 ha, with moderate shade cover from native or planted trees mainly distributed near the fences between the paddocks. During 2013 and 2014, the flock was composed of approximately 600 sheep, and 15 deaths associated with tumors on the face were recorded in the Friesian Milchschaf and Finnish Landrace breeds.

In the second farm, located in Rincón del Colorado, Canelones $\left(34^{\circ} 69^{\prime} 20^{\prime \prime} \mathrm{S} 56^{\circ} 37^{\prime} 74^{\prime \prime} \mathrm{O}\right)$, the technical visit occurred in November 2017. The farm held 312 sheep, approximately 94 Friesian Milchschaf and 218 Finnish Landrace, grazing in an area of 120 ha with little shade cover not available in every paddock. The shade was provided by eucalyptus trees usually located near the fences. The animals grazed on improved pasture and received feed supplement before lambing. From 2013 to 2017, 18 deaths associated with tumors on the face were registered in the Friesian Milchschaf and Finnish Landrace breeds.

During flock inspection in the first property, tumor lesions located in the eyelids infiltrating into the eyes were identified in two (2.53\%) Friesian Milchschaf sheep aged $21 / 2$ and 3 years, whereas herd inspection in the second farm identified similar lesions in three animals (2.12\%) of this same breed aged 4 to 6 years: two of them showed neoplasms in the pinna and one in the eye and eyelid. The animals with eyelid and ocular lesions showed abundant lacrimation, apathy, and weight loss.

The tumors were locally infiltrative, nodular, approximately 2-3 cm in diameter, verrucous, firm, with dark surface, and whitish on cut section, with multifocal, yellowish granules. In the sheep with eyelid and/or ocular lesions, crusty epidermal proliferation was observed along the outer surface of the eyelids. Some of the sheep showed cavitary, plaque-like lesions (Fig.1A), and one ewe had intratumoral myiasis in the eye (Fig.1B). The eyelid and/or ocular masses were ulcerative, bled easily, and had deformed the upper and lower eyelids.

Microscopically, the neoplasms were classified as moderately-differentiated SCCs in one tumor affecting the eyelid and the eye (first property) and one tumor affecting the pinna (second property); the other three cases were defined as well-differentiated SCCs.

In the well-differentiated SCCs, multifocal-to-coalescing areas of concentrically arranged lamellar large keratin islands (keratin pearls) were observed, which were often associated with infiltrates of viable and degenerate neutrophils. The lesion was infiltrating, poorly delimited and nonencapsulated. The neoplastic cells were arranged in nests and supported by moderate fibrovascular stroma (Fig.1C). The cells were polygonal with partially distinct borders, prominent intercellular bridges, abundant homogeneous eosinophilic cytoplasm, with round-to-oval, central to paracentral nucleus and coarse basophilic chromatin with one to two prominent nucleoli. Mild anisocytosis and anisokaryosis was observed. The more superficial layer of the neoplastic mass showed multifocal areas of ulceration, hemorrhage, and neutrophilic infiltrate.

In the tumors classified as moderately-differentiated SCCs, a densely cellular, infiltrating, nonencapsulated mass was observed. The neoplastic cells were arranged in cords and nests supported by moderate fibrovascular stroma. The cells showed polygonal to spindled shape with partially distinct borders, moderate amount of homogeneous eosinophilic cytoplasm, round to oval central nucleus with coarse or 

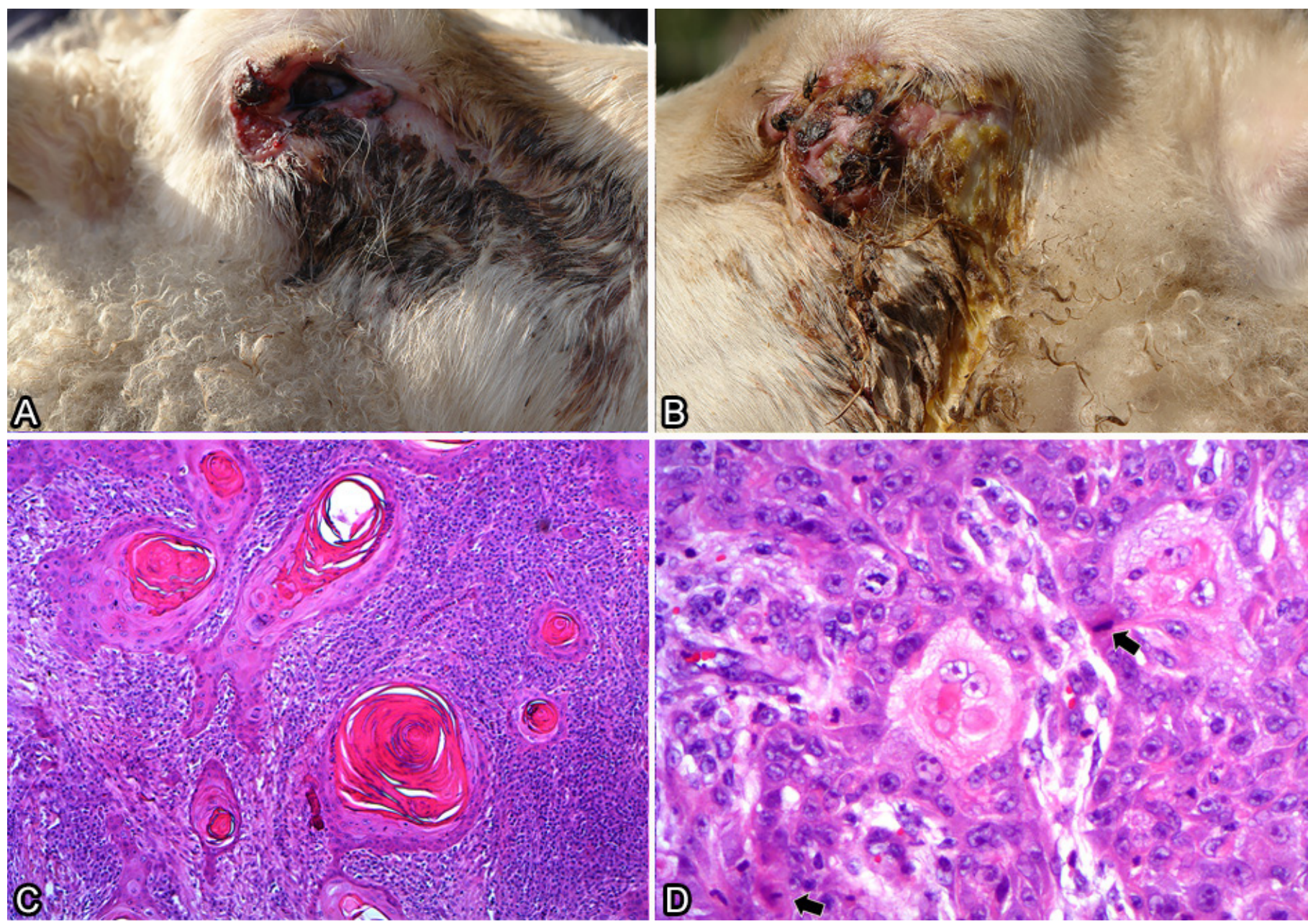

Fig.1 (A) Cavitary, plaque-like neoplasm in the lower eyelid. Ovine cutaneous squamous cell carcinoma. (B) Neoplastic proliferation in the eyelid with invasion of the eyeball and intratumoral myiasis. Ovine cutaneous squamous cell carcinoma. (C) Multiple keratin pearls surrounded by keratinocytes in the middle of the neoplastic tissue and abundant inflammatory infiltrate. Well-differentiated ovine cutaneous squamous cell carcinoma. HE, obj.5x. (D) Neoplastic cells of irregular arrangement, with occasional keratin formations, and frequent mitoses (arrows). Moderately-differentiated ovine cutaneous squamous cell carcinoma. HE, obj.20x.

vesicular chromatin, and one to two nucleoli; although cells with 3-5 nucleoli were occasionally observed. Rare keratin pearls, multinucleated cells, and individual keratinization were also observed (Fig.1D). Anisocytosis and anisokaryosis were moderate and there were large numbers of mitotic figures. In addition, multifocal neutrophilic inflammatory infiltrate and superficial ulcerated bleeding areas were found.

\section{DISCUSSION}

The diagnoses of SCCs were based on macroscopic and histological examination of the lesions in all cases, which were similar to those described by other authors in different sheep breeds such as Santa Inês and their crosses, Bergamacia (Macêdo et al. 2008), Corriedale, Ideal, and Ile de France (Ramos et al. 2007). Cases involving the Friesian Milchschaf breed have also been reported in Uruguay (García et al. 2018).

These neoplasms can emerge anywhere in the animal's body, but they predominate in non-pigmented areas clear of fleece where there is less protection from UV rays. Sheep of the Milchschaf breed have the head clear of fleece, the face is covered by pink whitish skin with no dark pigmentation and thin hair (ARCO 2017).

Most of the neoplastic masses were macroscopically classified as nodular tumors; however, some animals showed plaque-like neoplastic lesions. The tumors assessed were verrucous and papillary, resembled a cauliflower, and bled easily, and the plaque-like lesions were characterized mainly by the presence of ulcerated, cavitary areas (Fernandes 2007, Ramos et al. 2007, Goldschmidt \& Goldschmidt 2016).

In order to categorize the SCCs according to their differentiation, several histological characteristics were evaluated based on the classification criteria described by Goldschmidt \& Goldschmidt (2016), which classify these neoplasms as well-differentiated, moderately-differentiated and poorly-differentiated. Because keratinocytes are the cellular origin of this neoplasm, it is mainly characterized by keratin formation. Well-differentiated tumors produce large amounts of keratin, deposited in the form of concentric islands, known as keratin pearls, and well-differentiated cellular bridges. In moderately-differentiated lesions, keratin pearls are scarce, and their intercellular bridges are more difficult 
to identify. In poorly-differentiated neoplasms, individual cell keratinization is observed. In addition to the keratinocyte characteristics, other histological findings associated with SCC are squamous differentiation, cellular pleomorphism, mitotic activity, and invasiveness.

Solar radiation is the sum of visible light plus ultraviolet (UV) radiation. Approximately $95 \%$ of UV radiation is UVA and $5 \%$ of it is UVB; the latter being more efficient in causing neoplasms. Severity of solar radiation depends on several factors, namely, exposure time; reflection of the Sun's rays on the surface (sand, snow, water, etc.); meteorological conditions; altitude and latitude (Young 2009). UV radiation causes mutations in the p53 gene, which is an important regulator of cell proliferation and growth, involved in carcinogenesis (Bruins et al. 2004). According to the classification of the World Health Organization (WHO 2017) for latitude $52^{\circ} \mathrm{N}$ (a region close to the East and North Friesland), the incidence of UV rays ranges from 2 to 5 (low-to-moderate level) in spring, and 3 to 7 (moderate-to-high level) in summer, whereas the levels for latitude $34^{\circ} \mathrm{S}$ (La Estanzuela and Rincón del Colorado) are 5 to 9 (moderate to very high in spring, and 7 to 10 (high to very high) in summer. The differences observed in the UV radiation levels indicate a greater potential for damage to the skin and conjunctiva, sites where the tumors occurred, at latitude $34^{\circ} \mathrm{S}$ than at the place of origin of the breed (latitude $52^{\circ} \mathrm{N}$ ).

The high relative prevalence of tumors in Milchschaf sheep in Uruguay is possibly associated with poor adaptation of these animals to the local climate and breeding system. In Germany, where this breed was developed, sheep are raised under intensive or semi-intensive system, for dairy production, in humid temperate climate, and remain confined for long periods. In contrast, in Uruguay, they are bred under extensive systems, intended for meat production, in temperate climate, and subjected to higher UV levels. These factors potentially intensify the exposure of animals to UV rays, which together with the morphological characteristics of the Milchschaf breed (white, non-pigmented skin and face clear of fleece), increased the frequency of neoplasms compared with other breeds in Uruguay (Garcia et al. 2018).

A study conducted in Rio Grande do Sul state, Brazil, described high prevalence $(9.1 \%)$ of SCC in the perineum in a flock of Ile de France sheep (Schild et al. 1995). The authors suggest that this high prevalence was due to the greater susceptibility of this breed to the disease associated with several factors, including lack of skin pigmentation and mucocutaneous junction of the vulva, small amount of fleece in the perineum, and very short sectioning of the tail (Schild et al. 1995). In this case, the higher susceptibility to the disease could also be related to the fact that the Ile de France breed comes from regions with lower levels of radiation incidence than Rio Grande do Sul state.

\section{CONCLUSIONS}

The high prevalence of squamous cell carcinoma (SCC) should be considered by farmers intending to introduce European sheep breeds with non-pigmented, clear of fleece skin in Uruguay and other countries in the region.

Reducing exposure of animals to solar radiation, providing larger shaded areas, and crossing them with pigmented breeds could be appropriate measures to reduce the risk of SCC.

\section{REFERENCES}

Alberti A., Pirino S., Pintore F., Addis M.F., Chessa B., Cacciotto C., Cubeddu T., Anfossi A., Benenati G., Coradduzza E., Lecis R., Antuofermo E., Carcangiu L. \& Pittau M. 2010. Ovis aries papillomavirus 3: a prototype of a novel genus in the family Papillomaviridae associated with ovine squamous cell carcinoma. Virology 407(2):352-359. <http://dx.doi.org/10.1016/j. virol.2010.08.034><PMid:20863546>

ARCO 2017. Padrão Racial East Friesian. Associação Brasileira de Criadores de Ovinos, Bagé. Available at <http://www.arcoovinos.com.br/index. $\mathrm{php} / \mathrm{mn}$-srgo/mn-padroesraciais/46-east-friesian> Accessed on Nov. 15, 2017.

Barbosa J.D., Duarte M.D., Oliveira C.M.C., Reis A.B., Peixoto T.C., Brito M.F. \& Peixoto P.V. 2009. Carcinoma de células escamosas perineal em cabras no Pará. Pesq. Vet. Bras. 29(5):421-427

Bruins W., Zwart E., Attardi L.D., Iwakuma T., Hoogervorst E.M., Beems R.B., Miranda B., Oostrom C.T., Berg J., Aardweg G.J., Lozano G., Steeg H., Jacks T. \& Vries A. 2004. Increased sensitivity to UV radiation in mice with a p53 point mutation at Ser389. Mol. Cel. Biol. 24(20):8884-8894. <http:// dx.doi.org/10.1128/MCB.24.20.8884-8894.2004> <PMid:15456863>

Carvalho F.K.L., Dantas A.F., Riet-Correa F., Andrade R.L., Nóbrega Neto P.I., Miranda Neto E.G., Simoes S.V.D. \& Azevedo S.S. 2014. Estudo retrospectivo das neoplasias em ruminantes e equídeos no semiárido do Nordeste Brasileiro. Pesq. Vet. Bras. 34(3):211-216. <http://dx.doi.org/10.1590/ S0100-736X2014000300003>

Fernandes C.G. 2007. Neoplasmas em ruminantes e equinos, p.650-656. In: Riet-Correa F., Schild A.L., Lemos R.A.A. \& Borges J.R.J. (Eds), Doenças de Ruminantes e Equídeos. Vol.2. 3aㅗ ed. Pallotti, Santa Maria.

García J.A., Quinteros C., Romero A.\& Dutra F. 2018. Occurrence of squamous cell carcinoma in Milchschaf sheep in Uruguay. Ciência Rural 48(1):e20170406. <http://dx.doi.org/10.1590/0103-8478cr20170406>

Goldschmidt M.H. \& Goldschmidt K.H. 2016. Epithelial and melanocytic tumors of skin, p.88-141. In: Meuten D.J. (Ed.), Tumors in Domestic Animals. 5th ed. John Wiley and Sons, Ames, Iowa. <http://dx.doi. org/10.1002/9781119181200.ch4>

Macêdo J.T., Riet-Correa F., Dantas A.F.M. \& Simões S.V.D. 2008. Doenças da pele em caprinos e ovinos no semi-árido brasileiro. Pesq. Vet. Bras. 28(12):633-642.<http://dx.doi.org/10.1590/S0100-736X2008001200013>

Mauldin E.A. \& Peters-Kennedy J. 2015. Integumentary system, p.509-736. In: Maxie G. (Ed.), Jubb, Kennedy and Palmer's Pathology of Domestic Animals. Vol.1. 6th ed. W.B. Saunders, Philadelphia.

Ramos A.T., Norte D.M., Elias F. \& Fernandes C.G. 2007. Carcinoma de células escamosas em bovinos, ovinos e equinos: estudo de 50 casos no sul do Rio Grande do Sul. Braz. J. Vet. Res. Anim. Sci. 44(Suppl.):5-13.<http://dx.doi. org/10.11606/issn.1678-4456.bjvras.2007.26583>

Schild A.L., Riet-Correa F., Mendez M.C. \& Ferreira J.L.M. 1995. Boletim do Laboratório Regional de Diagnóstico. Número 15, Gráfica Universitária, Pelotas, RS, p.18-20.

Vitiello V., Burrai G.P., Agus M., Anfossi A.G., Alberti A., Antuofermo E., Rocca S., Cubeddu T. \& Pirino S. 2017. Ovis aries papillomavirus 3 in ovine cutaneous squamous cell carcinoma. Vet. Pathol. 54(5):775-782. <http://dx.doi. org/10.1177/0300985817705171><PMid:28494708>

WHO 2017. Ultraviolet Radiation (UV). World Health Organization, Geneva. Available at <http://www.who.int/uv/intersunprogramme/activities/ uv_index/en/> Accessed on Dec. 11, 2017.

Young C. 2009. Solar ultraviolet radiation and skin cancer. Occup. Med. 59(2):8288. <http://dx.doi.org/10.1093/occmed/kqn170> <PMid:19233827> 